\title{
Retraction Note to: Physcion 8-0- $\beta$-glucopyranoside exhibits anti-leukemic activity through targeting sphingolipid rheostat
}

\author{
Editorial Office of Pharmacological Reports ${ }^{1}$
}

Published online: 6 November 2020

(c) Maj Institute of Pharmacology Polish Academy of Sciences 2020

\section{Retraction Note to: \\ Pharmacological Reports 70(2018) 853-862 \\ https://doi.org/10.1016/j.pharep.2018.03.003}

The Editor in Chief has retracted this original article because of concerns regarding a number of figures presented in this work, which question the integrity of the data. Specifically, unexpected similarities have been found between plots presented in Figs. $4 \mathrm{c}$ and $5 \mathrm{c}$ and those published elsewhere with different labels: Fig. 1c in [1], Fig. 4b in [2] and Fig. 7b in ([3], retracted).

The authors were unable to provide raw data.

Author Lei Sheng agreed to retraction but has not stated if they agree to this retraction notice. The editor was not able to obtain a current email address for the remaining authors.

\section{References}

[1] Wang Q, et al. Physcion 8-O- $\beta$-glucopyranoside suppresses tumor growth of hepatocellular carcinoma by downregulating PIM1. Biomed Pharmacother. 2017;92:451-8. https://doi.org/10.1016/j.biopha.2017.05.110.

The original article can be found online at https://doi. org/10.1016/j.pharep.2018.03.003.

Editorial Office of Pharmacological Reports

https://www.springer.com/journal/43440
[2] Yang X, et al. Physcion 8-O- $\beta$-glucopyranoside alleviates oxidized low-density lipoprotein-induced human umbilical vein endothelial cell injury by inducing autophagy through AMPK/SIRT1 signaling. J Cardiovasc Pharmacol. 2019;74(1):53-61. https://doi.org/10.1097/FJC.0000000000 000680 .

[3] Liu K, et al. Hispidulin suppresses cell growth and metastasis by targeting PIM1 through JAK2/STAT3 signaling in colorectal cancer. Cancer Sci. 2018;109(5):1369-81. https://doi.org/10.1111/cas.13575.

Publisher's Note Springer Nature remains neutral with regard to jurisdictional claims in published maps and institutional affiliations. 